\title{
Peran Orang Tua dalam Mendukung Kegiatan Pembelajaran di Rumah pada Masa Pandemi
}

\author{
Agustien Lilawati ${ }^{1} \bowtie$ \\ Pendidikan Islam Anak Usia Dini, Universitas Muhammadiyah Gresik \\ DOI: $\underline{10.31004 / \text { obsesi.v5i1.630 }}$
}

\begin{abstract}
Abstrak
Studi yang dilakukan memiliki tujuan sebagai pendeskripsian peran orangtua yang dilaksanakan untuk mendukung kegiatan pembelajaran pada pendidikan anak usia dini di RA Team Cendekia Surabaya. Metode penelitian yang digunakan adalah kualitatif dengan pendekatan studi kasus. Pengumpulan data melalui wawancara, observasi, serta dokumentasi dengan analisis data deskriptif. Teknik analisis data terdiri dari reduksi data, sajian data, dan penarikan simpulan. Hasil penelitian menunjukkan bahwa (1) peran orang tua terhadap penerapan pembelajaran di rumah pada masa pandemi dalam mendidik anak meliputi pendampingan dan sebagai motivator. (2) dampak peran orang tua terhadap pembelajaran pada masa pandemi di RA Team Cendekia Surabaya, orangtua memfasilitasi keterlibatan kegiatan pembelajaran dalam pendidikan anak usia dini di RA Team Cendekia Surabaya.
\end{abstract}

Kata Kunci: peran orangtua; pembelajaran dirumah; pendidikan.

\begin{abstract}
This study aims to explain the role of parents carried out in supporting learning activities in early childhood education in RA Team Cendekia Surabaya. Methods of data collection using interviews, observation, and documentation with descriptive data analysis. Data analysis techniques consist of data reduction, data presentation, and drawing conclusions. The results showed that (1) the role of parents in the application of learning at home during the pandemic in educating children includes mentoring and as a motivator. (2) the influence of the role of parents on learning during the pandemic in the RA Scholar Team in Surabaya, parents facilitate the involvement of learning activities in early childhood education in the RA Team Cendekia Surabaya.
\end{abstract}

Keywords: parental role; home study; education.

Copyright (c) 2020 Agustien Lilawati

$\triangle$ Corresponding author:

Email Address : agustin@umg.ac.id (Randu Agung Kebomas kabupaten Gresik Jawa Timur)

Received 4 June 2020, Accepted 10 July 2020, Published 18 July 2020

\section{PENDAHULUAN}

Anak usia dini merupakan anak yang usianya antara 0-6 tahun. Usia tersebut menjadi momen yang sangat mendesak bagi potensi seorang anak agar dapat berkembang sebagaimana yang dijelaskan oleh Feldman dalam (Asmani, 2009: 24) bahwasannya masa balita adalah keemasan masa bagi manusia yang tak dapat diulang, dikarenakan menjadi momen yang terpenting sebagai pembentuk asas-asas karakter, kapabilitas berpikir, intelektual, kreatifitas, serta kapabilitas untuk melakukan sosialisasi. Selain itu, masa tersebut dikatakan masa emas disebabkan adanya tanda dari perkembangan kuantitas serta kegunaan 
sel-sel saraf otak anak, dengan adanya hal tersebut, momen tersebut menjadi masa emas yang penting sekali untuk mengembangkan sosial, intelektual serta emosi anak di waktu yang akan dihadapinya kelak yang didasari pada intensi serta mengapresiasi uniknya masing-masing. Dewantara dalam Asmani, (2009: 18) mengungkapkan bahwasannya anak mendapatkan pendidikan dalam rangka melakukan pengembangan (mencerdaskan) akalnya, menambah kepekaan hati (mencerdaskan hati), serta menunjang peningkatan kreatifitas.

Orang tua memiliki kewajiban dalam mendidik anak-anaknya. Irma et al. (2019) dalam penelitiannya mendapatkan keterlibatan orang tua dalam pendidikan anak usia dini perlu sinergi dengan ragam upaya program maupun kegiatan yang disesuaikan dengan analisis kendala-kendala dari pihak orang tua meliputi faktor status sosial, faktor bentuk keluarga, faktor tahap perkembangan keluarga, dan faktor model peran. Jadi dapat dikatakan bahwa keluarga memiliki peran besar dalam proses pendidikan anak.

Keluarga merupakan pondasi pendidikan yang pertama bagi anak, (Hayati, 2011: 13) mengatakan bahwa sikap orang tua sangat membantu dalam mengembangkan potensi anak, di antaranya yakni menghargai opini anak serta mendorong anak untuk mengutarakannya, menyediakan kesempatan bagi anak-anak dalam melakukan perenungan, khayalan, berpikir, serta memperbolehkan anak dalam pengambilan keputusan secara individu dan memberi stimulus padanya agar senantiasa banyak bertanya serta memberi penguatan pada anak bahwasannya sikap orang tua menghargai rasa ingin mencoba hal baru, dilaksanakan dan menghasilkan, menunjang dan mendorong kegiatan anak, menikmati keberadaannya bersama anak, memberi sanjungan yang sungguh-sungguh kepada anak, mendorong kemandirian anak dalam bekerja dan menjalin hubungan kerja sama yang baik dengan anak.

Peneliti Karen Smith Conway, profesor ekonomi di University of New Hampshire, dan rekannya Andrew Houtenville, rekan peneliti senior di New Editions Consulting, menemukan bahwa keterlibatan orang tua memiliki efek positif yang kuat pada siswa yang memiliki prestasi. "Parental Effort, School Resources, and Student Achievement," (Olsen, 2010: 37) mengungkapkan bahwa "upaya orang tua secara konsisten dikaitkan dengan tingkat pencapaian yang lebih tinggi, dan besarnya pengaruh upaya orang tua sangat besar. Kami menemukan bahwa sekolah-sekolah perlu meningkatkan pengeluaran per murid lebih dari \$ 1.000 untuk mencapai hasil yang sama dengan yang diperoleh dengan keterlibatan orang tua.."

Berdasarkan Siaran Pers, Nomor: 137/sipres/A6/VI/2020 Aturan Kemendikbud yang sudah beredar di kala pandemi Corona Virus Disease (Covid-19) detik ini menciptakan kejadian yang menarik dalam lingkup pendidikan di Indonesia terutama meskipun pandemi Corona Virus Disease (Covid-19) sudah menyebar secara luas menurut sumber bbc.com sudah sampai di 209 negara serta sudah memporak-porandakan seluruh aspek kehidupan manusia yang bermartabat, mulai kesehatan, pendidikan, sosio-komunikasi dan sosio-ekonomi, bahkan menyentuh dimensi implementasi ke-agamaan. Kejadian yang menarik ini adalah mengenai situasi sosial yang disebut juga group-situation, yaitu situasi kelompok sosial. Kesatuan sosial yang terdiri atas dua atau lebih individu yang telah mengadakan interaksi sosial secara intensif dan teratur, sudah dapat pembagian tugas, struktur, dan norma-norma tertentu (Kemendikbud, 2020).

Pendidikan adalah sebuah tanggung jawab bersama bukan hanya pemerintah, tetapi juga sekolah (guru), dan keluarga (orang tua) (Hatimah, 2016: 13). Sekolah dan keluarga masuk ke dalam kelompok primer. Dalam kelompok ini terdapat interaksi sosial yang lebih intensif dan lebih erat, yaitu face-to-face group, dimana setiap anggota dari sebuah kelompok sering menghadapi atau bertatap muka yang satu dengan yang lain, saling memahami dari dekat dan memiliki hubungan yang saling erat. Peranan kelompok primer ini dalam kehidupan individu sangat penting karena di dalam kelompok inilah khususnya keluarga manusia pertama-tama berkembang dan mendapatkan didikan sebagai makhluk sosial. Di kelompok inilah terajarkan kerangkanya yang memugkinkannya untuk mengembangkan sifatsifat sosial, antara lain mengindahkan norma-norma, melepaskan kepentingan dirinya 
demi kepentingan kelompok sosialnya, belajar bekerja sama dengan individu-individu lainnya, dan mengembangkan kecakapannya guna kepentingan kelompok.

Dalam pendapat Soerjono dan Soekanto (2004) menyatakan bahwa peran adalah aspek dinamis dari posisi seseorang untuk mengimplementasikan seperangkat hak dan kewajiban yang dimiliki seseorang. Ketika seseorang menggunakan hak dan kewajibannya sesuai dengan posisinya, menjalankan fungsinya. Peran adalah aspek dinamis dari situasi (negara). Ini memainkan peran ketika seseorang mengikuti posisinya dan menerapkan hak dan kewajibannya. Peran orang tua dalam mendampingi kesuksesan anak selama belajar di rumah menjadi sangat sentral, sekaitan dengan hal tersebut (WHO, 2020) merilis berbagai panduan bagi orang tua dalam mendampingi putra-putri selama pandemi ini berlangsung yang meliputi tips pengasuhan agar lebih positif dan konstuktif dalam mendampingi anak selama beraktivitas di rumah.

Pada prestasi akademik, sebagaimana yang diungkapkan oleh (Pinantoan (2013) dalam penelitian yang dilakukan menunjukkan pengaruh orang tua keterlibatan pada keberhasilan akademik siswa tidak boleh diremehkan. Pada hasil penelitian ini menetapkan pentingnya sistem pendukung yang diperoleh siswa dari rumah juga sama pentingnya sebagai kekuatan otaknya, etos kerja dan genetika yang semuanya bekerja dalam pencapaiannya tujuan hidup. Selanjutnya, siswa dengan dua orang tua yang beroperasi dalam peran suportif adalah 52\% lebih mungkin menikmati sekolah dan mendapatkan nilai A daripada siswa yang orang tuanya dilepaskan dengan apa yang terjadi di sekolah. Permasalahan tersebut sering terutama terjadi pada tahun-tahun awal tahun sekolah, di TK sampai kelas 5, ketika siswa dengan orang tua yang aktif berada hampir dua kali lebih mungkin untuk berhasil. Begitu siswa memasuki sekolah menengah, efeknya berkurang sedikit mungkin karena mereka matang selama waktu ini tetapi masih ada $22 \%$ perbedaan.

Orang tua pada awalnya berperan dalam membimbing sikap serta keterampilan yang mendasar, seperti pendidikan agama untuk patuh terhadap aturan, dan untuk pembiasaan yang baik (Nurlaeni \& Juniarti, 2017), namun perannya menjadi meluas yaitu sebagai pendamping pendidikan akademik. Prabhawani (2016) menyatakan bahwa pelaksanaan pendidikan merupakan tanggung jawab orang tua dan masyarakat sekitar, tidak hanya tanggung jawab lembaga pendidikan saja. Orang tua adalah bagian dari keluarga yang lebih besar, digantikan oleh keluarga inti orang tua dan anak-anak. Orang tua memainkan peran penting, mereka sangat berpengaruh dalam pendidikan anak-anak mereka, dan mereka bertanggung jawab atas pendidikan, perawatan dan bimbingan anak-anak mereka untuk mencapai tahap-tahap tertentu yang mempersiapkan mereka untuk kehidupan sosial.

Dalam pendapat (Gunarsa, 2004: 8), keluarga ideal (sempurna) memiliki dua orang yang memainkan peran penting, yaitu, sebagai ayah dan ibu, dua individu umumnya memainkan peran berikut: serta peran ibu. Peran seorang ibu adalah untuk memenuhi kebutuhan secara biologis dan fisik anaknya, bersabar, kasih sayang dan ketabahan dalam merawat keluarga, mendidik, mengelola dan mengendalikan anak-anak, dan memberikan contoh bagi anak-anak. Peran ayah adalah sebagai berikut: ayah sebagai sumber Tuhan, ayah sebagai konsep dan asuransi untuk suami, ayah berpartisipasi dalam pendidikan anak dan ayah sebagai wali, bijak atau hormat dari keluarga.

Berdasarkan penghasilan orang tua dapat memperjelas bahwa orang tua memainkan peran yang sangat penting dan berpengaruh dalam pendidikan anak-anak mereka. Anakanak menerima pendidikan pertama mereka karena ini adalah bentuk pendidikan pertama dari keluarga mereka, dan dari sinilah mereka berasal.

Bentuk peran orang tua sebenarnya adalah bentuk peran guru di sekolah. Peran orang tua adalah menjadi orang tua yang memotivasi dalam segala hal. Motivasi dapat diberikan dengan cara yang meningkatkan kebutuhan sekolah dan dapat memberikan semangat dalam pujian atau penghargaan untuk prestasi anak. Dalam hal ini peran orang tua adalah membimbing dan memberikan motivasi kepada anak, agar anak tetap bersemangat dalam melakukan kegiatan di rumah. Pada dasarnya anak memiliki motivasi untuk melakukan suatu hal, apabila ia mendapatkan sebuah dorongan dari orang-orang terdekat seperti orang tua 
(Yulianti, 2014). Karena besar kecil penghargaan yang diberikan kepada anak sangat berpengaruh, penghargaan yang diberikan sangat berharga dan lebih antusias untuk anakanak. Orang tua juga bisa menjadi teman yang bahagia untuk belajar atau belajar. Selain itu, orang tua ditugaskan sebagai guru untuk mengajar dan mendidik anak-anak mereka. Oleh karena itu, orang tua perlu lebih sabar dalam mengajar dan membimbing sebagai tugas guru di sekolah. Dalam melakukan ini, orang tua saling melengkapi dan sangat membantu dalam memecahkan masalah dan kesulitan yang dihadapi anak-anak di sekolah dan di rumah. Senada dengan pernyatan tersebut, Gusmaniarti \& Suweleh (2019) mendapati orang tua mempunyai peran dalam mengembangkan rasa percaya anak walau pun sebagian kecil masih ada yang mendampingi.

Singkatnya, peran orang tua sebagai saluran disiplin adalah untuk menanamkan dan menegakkan disiplin. Disiplin anak sangat penting, tetapi itu tidak berarti disiplin yang ketat. Anak-anak perlu terbiasa dengan kehidupan yang teratur. Berkenaan dengan upaya peningkatan nilai, orang tua dapat membuat jadwal tugas belajar di rumah dan jadwal belajar mereka. Anak merasa disiplin diterapkan secara teratur dari waktu ke waktu, jadi dia tidak merasa terikat dengan aturan, tetapi dia melakukannya dengan kesadaran sehari-hari. Akhirnya, peran orang tua sebagai manajer adalah bagi orang tua untuk melacak perkembangan kinerja anak-anak mereka dan mengendalikan perilaku mereka di rumah dan sekolah dengan mendekati informasi antara guru dan orang tua. Oleh karena itu, orang tua dapat menentukan alasan untuk perkembangan anak mereka, regresi dan merespons dengan bijak.

Selain itu, pendapat (Siregar, 2013: 8) menambahkan bahwa ada empat cara untuk meningkatkan peran orang tua dalam pendidikan anak-anak. Pertama, atur jadwal kegiatan anak dan waktu anak. Anak-anak diajarkan untuk belajar tidak hanya ketika mereka mendapatkan pekerjaan rumah dari sekolah dan ketika mereka menghadapi ujian, tetapi juga setiap hari. Setiap hari, anak-anak diajarkan untuk mengulangi pelajaran yang diberikan guru kepada mereka hari itu, dengan pemahaman bahwa mereka punya waktu untuk bermain. Kedua, pantau perkembangan kemampuan akademik anak. Orang tua diminta memeriksa nilai tes dan tugas anak. Ketiga, memantau perkembangan kepribadian, termasuk sikap, moral, dan perilaku anak-anak. Ini dapat dilakukan oleh orang tua yang menghubungi guru kelas mereka untuk belajar lebih banyak tentang perkembangan anak mereka di sekolah. Keempat, pantau efektivitas waktu sekolah di sekolah.

Lingkungan yang paling dekat dengan anak-anak untuk menyediakan pendidikan adalah lingkungan yang paling dekat dengan orang tua mereka dan kehidupan mereka, yang memiliki dampak luar biasa pada pertumbuhan dan perkembangan anak. Apabila terdapat kesalahan pengasuhan maka akan berdampak pada anak saat sudah dewasa. Sejalan dengan hal tersebut Rahmawati., (2015) menyatakan bahwa pengasuhan anak merupakan suatu kegiatan berkelanjutan melalui proses interaksi orang tua dan anak untuk mendorong pertumbuhan serta perkembangan anak yang optimal. Terdapat beberapa hal yang dapat dilakukan orang tua untuk meningkatkan tumbuh kembang dan kesehatan anak (asah), yaitu dengan cara: memberi stimulus berupa memberikan cinta yang tulus dan kehangatan, memberi bentuk pengalaman secara nyata dengan menggunakan seluruh indra yang dimiliki oleh anak, melakukan interaksi melalui sentuhan, interaksi melalui pelukan, interaksi melalui senyuman, interaksi melalui nyanyian, mendengarkan dengan penuh perhatian menaggapi ocehan anak, mengajak bercakap-cakap dengan suara yang lembut, dan memberi rasa aman (Dariyo., 2004: 17).

Undang-undang No. 20 tahun 2003 pasal 28 bahwa bentuk PAUD yang terdapat di jalur formal harus memenuhi persyaratan dalam menyelenggarakan pendidikannya, seperti kurikulum yang berstruktur, tenaga pendidik, tata administrasi serta sarana dan prasarana (Undang-Undang Nomor 20 Tahun 2003 Tentang Sistem Pendidikan Nasional, 2003). Sebagaimana lembaga sekolah RA Team Cendikia Surabaya yakni terwujudnya anak didik yang cerdas dan terampil di tengah masa pandemi Covid 19.Berdasarkan uraian permasalah tersebut, tujuan dalam penelitian ini adalah untuk mendeskripsikan dan menjelaskan terkait 
1) Bagaimana peran orang tua terhadap penerapan pembelajaran di rumah pada masa pandemi dan 2) Adakah pengaruh peran orang tua terhadap pembelajaran pada masa pandemi di RA Team Cendekia Surabaya. Dengan tujuan penelitian mengetahui peran orang tua untuk melaksakan kegiatan pembelajaran di rumah pada masa pandemi, di RA Team Cendekia Surabaya.

\section{METODOLOGI}

Metodologi kualitatif sebagai prosedur pelaksanaan penelitian untuk menghasilkan data dalam bentuk bahasa deskriptif atau verbal, atau dari prosedur politik (Moleong, 2002: 112). Jenis penelitian ini adalah studi kasus. Kegiatan ini diadakan di rumah orang tua siswa dari tim peneliti Surabaya pada bulan April hingga Mei 2020. Kehadiran peneliti merupakan tolok ukur keberhasilan atau pemahaman terhadap beberapa kasus. Peneliti bertindak sebagai instrumen utama dalam pengumpulan data atau instrumen kunci. Teknik pengumpulan data utama untuk survei ini adalah wawancara, catatan, dan dokumentasi. Teknologi analisis data yang menganalisis data pencarian menggunakan model interaktif dari Miles dan Huberman. Penelitian ini menggunakan Triangulasi untuk menguji validitas data. Metode triangulasi yang digunakan adalah triangulasi metode dan sumber dengan memeriksa catatan wawancara, catatan lapangan, survei, dan catatan dokumen dari berbagai sumber data. Sampel penelitian dilakukan pada orang tua siswa dari dari RA Team Cendekia Surabaya. Untuk lebih jelasnya mengenai data analisis studi kasus dapat dilihat pada gambar bagan di bawah ini:

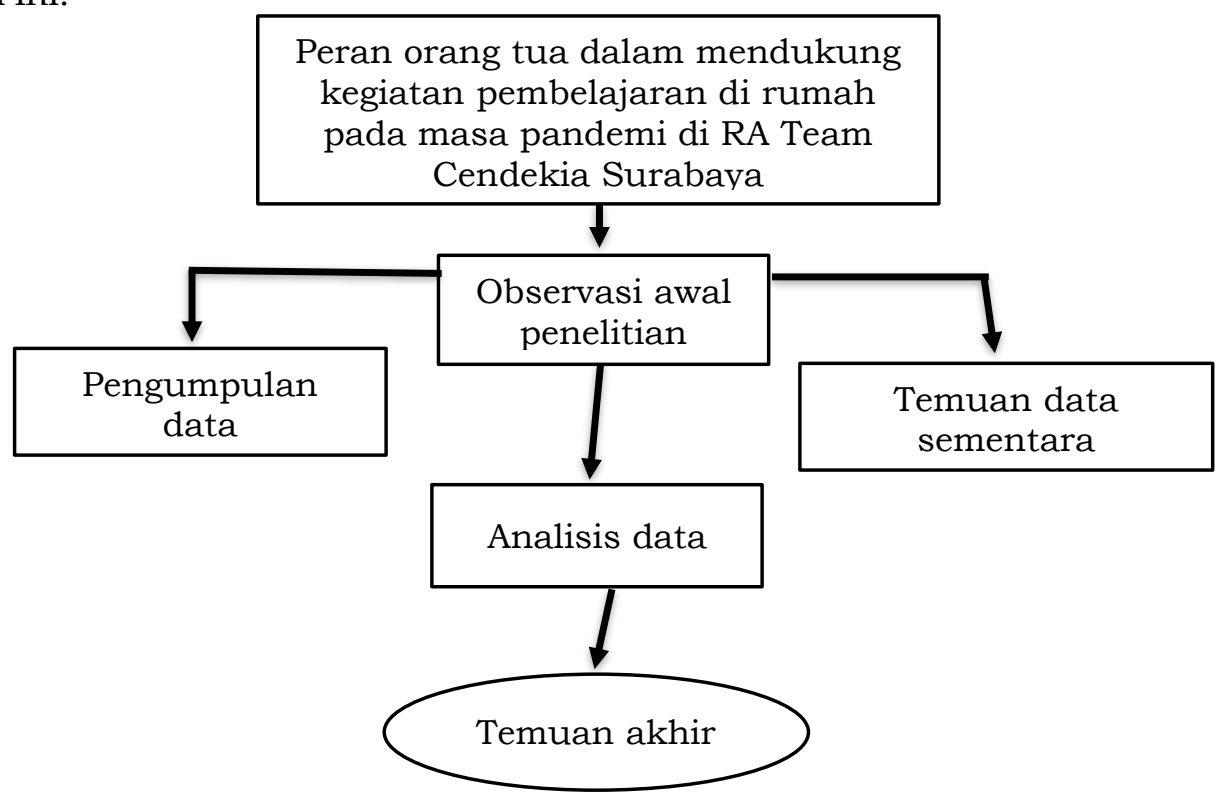

Gambar alur penelitian

\section{HASIL DAN PEMBAHASAN}

\section{Peran orang tua terhadap penerapan pembelajaran di rumah pada masa pandemi}

Realisasi peran orangtua dalam mendukung kegiatan pembelajaran di rumah wali murid RA Team Cendekia Surabaya selama masa pandemi berlangsung. Kontribusi orang tua untuk anak usia dini di dunia pendidikan sangat, berpengaruh pada berkembangnya pendidikan anak. Kontribusi orang tua pada pendidikan harus dilakukan secara berkelanjutan dalam memotivasi, memberi arahan dan memberi dorongan serta memberi sarana agar dapat tercapai keidealan dalam mendidik anak. Melalui kegiatan-kegiatan untuk mendapatkan informasi dalam pelaksanaan penulisan penelitian, kegiatan pengambilan wawancara dilakukan dengan cara pengajuan pertanyaan kepada informan, mengenai peran orangtua dalam kegiatan pembelajaran yang diaksanakan selama masa pademi covid-19 pada anak usia dini di rumah, wawancara dilakukan kepada orangtua, pada tahap sebagai 
triangulasi dalam penelitian ini pertanyaan di bagi menjadi tiga bagian yang melikupi pertanyaan mengenai; peran orang tua terhadap penerapan pembelajaran di rumah pada masa pandemi dan pelaksanaan peran orang tua terhadap pembelajaran pada masa pandemi di RA Team Cendekia Surabaya.

Penelitian pertama mengenai peran orangtua terhadap pembelajaran yang dilaksanakan dirumah. Peran serta orang tua siswa dalam sistem belajar dirumah ini tidak bisa dipungkiri. Jika Dokter sebagai garda terdepan dalam menangani Covid-19, maka Orang tua baik ayah maupun ibu sebagai garda terdepan yang mengawal anak-anaknya tetap belajar dirumah masing-masing. Orang tua memiliki tanggung jawab utama dalam proses pertumbuhan dan perkembangan anaknya. Dengan begitu orang tua menjadi sumber pertama anak untuk belajar karena pada dasarnya anak memiliki dorongan untuk meniru suatu pekerjaan, baik itu dari orang tua maupun dari orang lain (Taubah, 2016). Baik atau buruknya suatu didikan yang diberikan orang tua akan berpengaruh terhadap perkembangan dan pertumbuhan anak itu sendiri. Karna menurut (Fadlillah, 2012: 35) mengatakan bahwa lingkungan keluarga bagi setiap anak, segala tingkah laku maupun yang muncul pada diri anak akan mencontoh kedua orang tuanya. Oleh karena itu, orang tua memiliki peranan yang sangat penting bagi anaknya sendiri. Menurut (Ahmadi, 2004: 43) menyatakan peran orang tua adalah suatu hal kompleks pengharapan manusia terhadap caranya individu harus bersikap yang mempunyai tanggung jawab dalam keluarga. Hal ini memiliki arti bahwa peran orang tua terhadap anak memiliki banyak sekali kewajiban dan tanggung jawab, yang salah satunya adalah bidang pendidikan, baik formal maupun non-formal. Di mana dengan pendidikan, anak mendapatkan suatu pencapaian atau bahkan menjadi manusia yang siap menghadapi tantangan di masa depan.

Pembelajaran yang dilaksanakan dirumah merupakan upaya dalam mempererat jalinan kekeluargaan antara orang tua dan anak. Peran orangtua bertanggungjawab sebagai motivator. Motivasi dapat diberikan dengan cara orang tua berperan sebagai guru di sekolah. Kegiatan belajar anak yang dilaksanakan dirumah disesuaikan dengan kebutuhan anak. Dalam hal ini orangtua menjadi sosok guru yang mampu memotivasi anak di rumah, dalam memberikan kegiatan anak dirumah orangtua memiliki peran sebagai pendidik yang utama. Kegiatan yang diberikan kepada anak di sesuaikan dengan tingkat perkembangan anak, berkolaborasi dengan guru juga berperan aktif dalam memberikan kegiatan pembelajaran orangtua bertindak sebagai pelaksana kegiatan pembelajaran. Selanjutnya, orang tua sebagai guru yaitu memiliki tugas mendidik dan mengajar anak-anaknya. Oleh karenanya orangtua dituntut untuk bersikap lebih sabar dalam membimbing serta mengarahkan mereka sebagaimana tugas guru di sekolah sehingga bisa saling melengkapi dan sangat membantu memecahkan masalah-masalah atau kesulitan-kesulitan yang dihadapi anak-anak baik di sekolah maupun di rumah. Seperti yang diungkapkan oleh Zahrok, S., \& Suarmini, (2018) bahwa keluarga berperan penting dalam menanamkan kebiasaan dan pola tingkah laku, serta menanamkan nilai, agama, dan moral sesuai dengan usia dan kultur di keluarganya.

Orangtua yang bertindak sebagai pelaksana pembelajaran dirumah, menjadi guru dalam melaksanakan kegiatan pembelajaran di laksanakan sesuai dengan tugas yang disusun oleh guru di sekolah. Peran orangtua sebagai pengganti guru, menyampaikan materi pembelajaran yang telah disiapkan. Sejalan dengan yang diungkapkan oleh (Rompas, 2018) yang menyatakan bahwa orang tua memiliki peran yang sangat penting dalam hal mendidik anak, salah satunya adalah menjadi dan memberikan contoh yang baik untuk anak, selain itu memberikan peringatan dan nasihat pada anak juga merupakan hal penting yang harus dilakukan orang tua agar selalu hidup bersih kepada anak. Upaya untuk memfasilitasi keluarga termasuk dalam seluruh kategori, yang dapat dilihat dari sarana dan prasarana yang dimiliki, kemudian dari karakteristik orang tua tentang pelaksana (pembelajaran), di mana orang tua memberi anak-anak kebebasan lebih besar untuk memilih mainan mereka. Pada umumnya dari semua fasilitas yang dimiliki keluarga adalah bahwa mereka tidak memanfaatkan daerah rumah, karena mereka memiliki pengetahuan yang terbatas tentang orang tua dan tempat mereka sendiri. Dalam pelaksanaanya orangtua dengan penghasilan 
rendah yang bekerja dan cenderung tidak berkontribusi terhadap kekurangan sarana yang ada. Orangtua cenderung memanjakan anak dengan game yang dibeli, dan orang tua tidak terlalu memperhatikan keselamatan, kompatibilitas, dan kebersihan. Beda dengan orangtua dengan tipe pekerja memiliki interaksi yang buruk antara orang tua dan anak. Interaksi yang lemah ini mengurangi keefektifan pengasuhan anak. Ini berbeda dengan orang tua yang tidak bekerja yang selalu membawa anak-anak mereka.

Hal lain yang membedakan tingkat peran orang tua dalam belajar anak di rumah adalah perbedaan dalam status pendidikan orang tua antara orang tua yang bekerja dan mereka yang tidak bekerja. Ketika datang untuk merancang permainan untuk orang tua dengan pendidikan menengah atau lebih tinggi, orangtua memiliki ide yang sangat bagus dengan berbagai kegiatan sehari-hari seperti makan bersama dan membaca dengan keras sebelum tidur. Orang tua yang kurang berpendidikan daripada sekolah menengah kurang bersedia untuk membuat dan berkomunikasi dengan baik dengan anak-anak mereka. Dengan kata lain, guru dan orang tua membuat keputusan, seperti kebebasan untuk memutuskan sendiri, dalam kegiatan belajar mereka sendiri. Kemudian, dari perspektif peran orang tua ketika kegiatan bermain dilakukan, orang tua yang bekerja dan tidak aktif memainkan peran yang memadai dalam kegiatan bermain anak-anak mereka. Anak-anak bermain sesuai dengan keinginan dan orang tua menghabiskan waktu bersama dengan anak bertindak sebagai pengawas.

Keberhasilan pembelajaran anak usia dini merupakan tanggung jawab bersama dan kewajiban pemerintah dan lembaga sekolah, tetapi guru pertama untuk orang tua dan anakanak sebagai guru berperan dalam keberhasilan dan kegagalan pembelajaran anak-anak. Karena sebab itu, dimasukkannya anak-anak dalam pendidikan mereka sangat mempengaruhi pencapaian minat anak-anak dan hasil belajar. Beberapa alasan mengapa orang tua kurang terlibat dalam pendidikan anak-anak terkait dengan pendidikan anak usia dini.

Peran orang tua dalam melakukan pembelajaran berbasis rumah memiliki banyak faktor yang pertama kali memengaruhi faktor status sosial seperti pendidikan, pekerjaan, dan pendapatan orang tua. Berdasarkan faktor pertama, dapat disimpulkan bahwa orang tua sangat tertarik untuk mendidik anak-anak mereka hanya jika partisipasi mereka berbeda. Selain itu, faktor pendapatan orang tua juga mempengaruhi pentingnya kebutuhan dalam mendukung pembelajaran anak. Sekolah juga bekerja dengan orang tua dan guru. Pekerjaan sekolah tentang keterlibatan orang tua dalam pendidikan anak usia dini dalam RA Team Cendekia Surabaya telah sangat berhasil, tetapi membutuhkan lebih banyak kegiatan. Kegiatan Bersama Orang Tua dan Guru dalam Komunikasi untuk Belajar dalam RA Team Cendekia Surabaya.

\section{Dampak peran orang tua terhadap pembelajaran pada masa pandemi di RA Team Cendekia Surabaya.}

Pelaksanaan pembelajaran dirumah, banyak dari orang tua memberikan motivasi selama siswa dituntut untuk belajar dari rumah karena himbauan pemerintah mengenai covid-19, hal ini juga yang membuat tidak sedikit orang tua yang sengaja untuk meluangkan waktunya demi dapat membantu proses pembelajaran anaknya selama di rumah. Banyak dari orang tua yang setuju jika selama pembelajaran di rumah, orang tua lah yang juga ikut membantu mengerjakan tugas yang diberikan oleh guru. Walaupun tidak sedikit juga yang merasa hal ini menjadi tambahan aktivitas orang tua selain mengerjakan pekerjaan rumah tangga. Hal ini sesuai dengan pendapat (Abdulrachman, 2020) bahwa mendampingi anak belajar dari rumah, sambil orangtua mengerjakan pekerjaan yang harus diselesaikan dari kantor atau dari rumah memang menjadi tantangan tersendiri, yang perlu dingat adalah orangtua di rumah bukan untuk menggantikan semua peran guru di sekolah.

Orang tua adalah pendidik memahami bahwa belajar tidak hanya ketika perlu diterapkan dan dikoordinasikan antara guru dan orang tua dengan orang tua di lingkungan sekolah. Peran pengawasan menunjukkan bahwa dalam keluarga, orang tua merupakan 
subsistem terkait interaksi orang tua dengan anak, yang di dalamnya berperan untuk melindungi, membesarkan dan mendisiplinkan anak (Pratiwi et al., 2018). RA Team Cendekia Surabaya memiliki buku laporan mengenai kemajuan belajar untuk siswa dan orang tua. Buku ini berisi tugas berkelanjutan yang perlu dilaksanakan orang tua/wali untuk menentukan apa yang orang tua/wali pelajari di sekolah dan tantangan baru yang akan diajarkan dalam pembelajaran selanjutnya. Koleksi dibuat melalui aplikasi "whatsapp" antara guru kelas dan orang tua/wali untuk memfasilitasi distribusi informasi, dan guru harus menjadi orang tua untuk mendukung aplikasi tanpa smartphone. Siswa yang akan dikirim langsung setelah diterima oleh orang tua.

Dalam penulisan penelitian, menemukan bahwa mereka hanya keluarga kecil orang tua dan anak-anak, yang lain tidak banyak berpartisipasi dalam bermain, dan kegiatan bermain hanya dilakukan oleh orang tua mereka. Anggota keluarga yang lengkap dengan keluarga seperti orang tua, paman, bibi, saudara, saudari dan kakek-nenek, partisipasi orang lain dalam kegiatan bermain sangat baik karena mengarah pada kegiatan bermain yang baik. Bahkan jika anggota keluarga atau orang lain berpartisipasi dalam kegiatan bermain, yang berarti bahwa orang tua tidak memiliki jadwal harian untuk kegiatan anak-anak mereka, ada waktu luang yang cukup untuk bermain dan dimaksudkan ketika mereka ingin berpartisipasi. Orang lain harus melibatkan diri ketika aktivitas yang tidak ditandatangani, non-orangtua dilakukan. Kedua, dalam hal partisipasi teman sebaya, jumlahnya sangat besar dan beragam, dan anak-anak biasanya memilih sendiri.

Selama pembelajaran di rumah, tugas yang diberikan oleh guru tidak sedikit dari orang tua yang merasa tugas yang diberikan lebih banyak dan terlihat sulit. Namun walaupun begitu, orang tua tidak menaruh rasa benci namun sebagian besar orang tua senang karena tugas dinilai mampu membantu siswa dalam mengerti materi lebih banyak karena latihan soal berupa tugas yang diberikan. Guru memberikan tugas karena terbatasnya waktu belajar dan sulitnya berinteraksi selama pembelajaran dirumah, oleh karena itu banyak dari sebagian guru yang mengganti hal tersebut menjadi pemberian tugas untuk memantapkan siswa mengenai materi yang dipelajari.

Hal ini sesuai dengan pendapat K Umam, D Puspitasari, (2020) bahwa dengan menggunakan sistem pembelajaran secara daring ini, terkadang muncul berbagai masalah yang dihadapi oleh siswa dan guru, seperti materi pelajaran yang belum selesai disampaikan oleh guru kemudian guru mengganti dengan tugas lainnya, hal tersebut menjadi keluhan bagi siswa karena tugas yang diberikan oleh guru lebih banyak. Banyak orang tua menilai bahwa melalui pembelajaran di rumah dapat mempererat hubungannya dengan anaknya, begitupun anaknya dinilai dapat melakukan pembelajaran di rumah dengan sangat baik, hal tersebut juga didukung oleh hasil penelitian Arifiyanti (2019) yang mengungkapkan bahwa hubungan anak dapat terjalin erat dengan orang tua apabila orang tua memberikan perhatian dan memiliki pola asuh yang demokratis. Orang tua juga merasa melalui pembelajaran di rumah, orang tua dapat melihat perkembangan anaknya dalam belajar. Terlihat dalam hal ini bahwa orang tua memiliki peran yang sangat besar selama terjadinya kegiatan pembelajaran di rumah, hal ini juga yang menegaskan bahwa orang tualah madrasah pertama bagi anakanaknya sebelum adanya pembelajaran di sekolah.

Kesiapan guru dalam penerapan pembelajaran daring juga menentukan keberhasilan pelaksanaan pembelajaran daring. Terdapat beberapa faktor yang membuat guru belum siap menghadapi pembelajaran daring, yaitu fasilitas yang kurang memadai baik dari pihak guru maupun dari pihak orang tua, dan masih terdapat orang tua yang menganggap bahwa pembelajaran daring ini sulit dilakukan (Ayuni et al., 2021)

Peran orangtua dalam melaksanakan kegiatan pembelajaran dirumah sangat berpengaruh tingkat penerapan pembelajaran dirumah selama masa pademi covid-19. Pengaruh yang paling terasa orangtua sebagai motivator kepada minat dan motivasi anak meningkat bila diberi kepercayaan dan tanggung jawab mengimplikasikan bakat atau potensi diri yang dikembangkan maupun dimiliki. Hal tersebut juga sesuai dengan Ardiyana R. D, Akbar Z, (2019) bahwa peran orang tua dalam pembelajaran anak usia dini mampu 
meningkatkan kepercayaan diri dan motivasi intrinsic anak. Orangtua mendampingi anak belajar dengan kasih sayang, pemberian materi pembelajaran disiapkan guru di terapkan kepada anak melalui orangtua harus sebisa mungkin bersabar sesuai dengan tahapan pembelajaran yang benar, contoh dalam kegiatan membaca anak didampingin orangtua yang memberikan materi selanjutnya ditirukan oleh anak. Kasih sayang juga dimaknai sebagai emosi untuk memfasilitasi kerja sama dan menjadi benteng bagi orang yang lemah atau menderita (Goetz et al., 2010, dalam Sofyan, Hasan Asari, 2019). Adanya kegiatan pembelajaran di rumah ini pun memiliki manfaat bagi siswa maupun orangtuanya, kebijakan pemerintah mengenai pembelajaran daring ini membuat kita semua sadar pentingnya mempelajari teknologi dan menggunakan teknologi secara positif. Paparan di atas menunjukkan bahwa selama ini, peran orang tua dalam pengasuhan dan perawatan lebih menonjol, sementara pendidikan akademik seringkali dialih tugaskan kepada pihak kedua yaitu sekolah sebagaimana yang dipaparkan (Rosdiana, 2006) bahwa faktanya kebanyakan orang tua masih merasa bahwa kewajibannya dalam mendidik anak telah usai setelah memasukannya ke suatu lembaga persekolahan.

Hal ini juga dapat menjadi pelajaran besar bagi dunia pendidikan Indonesia kedepannya untuk mengatasi berbagai permasalahan dalam dunia pendidikan sekarang ini. Semua orang tua memainkan peran aktif dalam membantu dan belajar anak. Misalnya, dalam proses belajar siswa, seperti belajar membuat kue, siswa dibawa langsung ke tempat membuat kue untuk latihan. Kegiatan akan dimodifikasi sesuai dengan topik pembelajaran yang dilakukan bekerja sama dengan lembaga dan masyarakat.

\section{SIMPULAN}

Partisipasi orang tua pada pendidikan anak usia dini mencakup berbagai inisiatif dan penyesuaian program yang dirancang khusus. Hasil penelitian menyimpulkan: (1) Orang tua merasa pembelajaran di rumah berjalan dengan efektif, hal ini dikarenakan pembelajaran di rumah banyaknya pemberian tugas yang dapat dibantu dibimbing pengerjaannya oleh orang tua di rumah; (2) Fasilitas pembelajaran dilaksanakan rumah dinilai tetap mampu meningkatkan tingkat pembelajaran di rumah dinilai tidak lebih menguntungkan bagi siswa menurut sebagian orang tua; (3) Banyak dari orang tua yang setuju jika selama pembelajaran di rumah, orang tua lah yang juga ikut membantu mengerjakan tugas yang diberikan oleh guru.

\section{UCAPAN TERIMA KASIH}

Terimakasih pada segenap orang tua siswa guru dan kepala Raudhatul Athfal Team Cendekia Surabaya.

\section{DAFTAR PUSTAKA}

Abdulrachman, P. (2020). Panduan Orangtua Mendampingi Anak Belajar dari Rumah dengan MIKIR. Kementerian Pendidikan Dan Kebudayaan Republik Indonesia. https:/ / guruberbagi.kemdikbud.go.id/artikel/panduan-orangtua-mendampingi-anak-belajardari-rumah-dengan-mikir/

Ardiyana, R. D., Akbar, Z., \& Karnadi, K. (2019). Pengaruh Keterlibatan Orang Tua dan Motivasi Intrinsik dengan Kepercayaan Diri Anak Usia Dini. Jurnal Obsesi : Jurnal Pendidikan Anak Usia Dini, 3(2), 494. https://doi.org/10.31004/obsesi.v3i2.253

Arifiyanti, N. (2019). Relationship between Authoritative Parenting Style and Preschools Prosocial Behavior. Jurnal Obsesi: Jurnal Pendidikan Anak Usia Dini, 3(2), 311. https://doi.org/10.31004/obsesi.v3i2.166

Ayuni, D., Marini, T., Fauziddin, M., \& Pahrul, Y. (2021). Kesiapan Guru TK Menghadapi Pembelajaran Daring Masa Pandemi Covid-19. Jurnal Obsesi: Jurnal Pendidikan Anak Usia Dini, 5(1), 414-421. https://doi.org/10.31004/obsesi.v5i1.579

Dariyo, A. (2004). Psikologi Perkembangan Remaja. Bogor: Ghalia Indonesia. 17.

Undang-Undang Nomor 20 tahun 2003 tentang Sistem Pendidikan Nasional, (2003). http:/ / www.inna- 
ppni.or.id/index.php/pendidikan-keperawatan

Dwita, R., \& Kurniawan, K. (2019). Pengaruh Struktur Modal, Ukuran Perusahaan dan Keputusan Investasi terhadap Nilai Perusahaan. STATERA: Jurnal Akuntansi Dan Keuangan, 1(1), 76-89. https:// doi.org/10.33510/statera.2019.1.1.76-89

Fadillah, M. (2012). Desain Pembelajaran PAUD Tinjauan Teoritik \& Praktik. Ar-Ruzz Media.

Gunarsa, S. D. (2004). Psikologi Praktis Anak, Remaja dan Keluarga (Cetakan. 7). PT. Gunung Mulia.

Gusmaniarti, G., \& Suweleh, W. (2019). Analisis Perilaku Home Service Orang Tua terhadap Perkembangan Kemandirian dan Tanggung Jawab Anak. Aulad: Journal on Early Childhood, 2(1), 27-37. https://doi.org/10.31004/aulad.v2i1.17

Irma, C. N., Nisa, K., \& Sururiyah, S. K. (2019). Keterlibatan Orang Tua dalam Pendidikan Anak Usia Dini di TK Masyithoh 1 Purworejo. Jurnal Obsesi : Jurnal Pendidikan Anak Usia Dini, 3(1), 214. https://doi.org/10.31004/obsesi.v3i1.152

Kemendikbud, R. I. (2020). Panduan Penyelenggaraan Pembelajaran pada Tahun Ajaran dan Tahun Akademik Baru di Masa Pandemi Covid-19: Satuan Pendidikan di Zona Kuning, Oranye dan Merah Dilarang Melakukan Pembelajaran Tatap Muka.

Maksum, A. (2013). Sosiologi Pendidikan. Sosiologi Pendidikan, 265.

Martha, G. (2015). Manajemen Strategi Pendidikan Anak Usia Dini (pp. 1-4). Diva press.

Moleong, L. J. (2005). Metodologi Penelitian Kualitatif,. Bandung: Remaja Rosdakarya.

Nurlaeni, N., \& Juniarti, Y. (2017). Peran Orang Tua Dalam Mengembangkan Kemampuan Bahasa Pada Anak Usia 4-6 Tahun. Jurnal Pelita PAUD, 2(1), 51-62. https://doi.org/10.33222/ pelitapaud.v2i1.196

Olsen, G., \& Fuller, M. L. (2008). The benefits of parent involvement: What research has to say. Education.Com. http://www.education.com/reference/article/benefits-parent-involvementresearch/

Pinantoan, A. (2013). The Effect of Parental Involvement on Academic Achievement.

Prabhawani, S. W. (2016). Pelibatan Orang Tua Dalam Program Sekolah di TK Khalifah. Jurnal Pendidikan Guru Pendidikan Anak Usia Dini, 2(5), 205-218.

Pratiwi, M. R., Mukaromah, M., \& Herdiningsih, W. (2018). Peran Pengawasan Orangtua Pada Anak Pengguna Media Sosial. Jurnal Penelitian Pers Dan Komunikasi Pembangunan, 22(1), 37-57. https:// doi.org/10.46426/jp2kp.v22i1.73

Rompas, Y. (2018). Hubungan Peran Orang Tua dengan Perilaku Hidup Bersih dan Sehat Anak Usia Sekolah di SD Inpres Talikuran Kecamatan Kawangkoan Utara. Jurnal Keperawatan, 6(1). https://doi.org/10.35568/abdimas.v1i2.327

Rosdiana, A. (2006). Partisipasi Orangtua Terhadap Pendidikan Anak Usia Dini : Jurnal Ilmiah VISI, 1(2), 62-72. https://media.neliti.com/media/publications/259930-partisipasi-orangtua-terhadappendidikan-89a4e534.pdf

Soekanto, S. (2004). Sosiologi Keluarga. Rineka Cipta.

Sofyan, S., Asari, H., \& Rasyidin, A. (2019). Islamic Traditional Manuscript in The State Islamic University of North Sumatra. Jurnal Tarbiyah, 26(2). https://doi.org/10.30829/tar.v26i2.555

Sugiyono. (2012). Metode Penelitian Kuantitatif. PT Fajar Interpratama Mandiri.

Sulastri, S., \& Ahmad Tarmizi, A. T. (2017). Peran Orang Tua Dalam Pendidikan Anak Usia Dini. Raudhatul Athfal: Jurnal Pendidikan Islam Anak Usia Dini, 1(1), 61-80. https://doi.org/10.19109/ra.v1i1.1526

Taubah, M. (2016). Pendidikan Anak Dalam Keluarga Perspektif Islam Mufatihatut Taubah. Jurnal Pendidikan Agama Islam (Journal of Islamic Education Studies), 3(1), 109. https:// doi.org/10.15642/jpai.2015.3.1.109-136

Umam, K., Puspitasari, D., \& Nurhadi, A. (2020). Penerapan Algoritma C4.5 Untuk Prediksi Loyalitas Nasabah PT Erdika Elit Jakarta. Jurnal Media Informatika Budidarma, 4(1), 65. https://doi.org/10.30865/mib.v4i1.1652

Umi Hanik. (2008). Strategi dan Metode Pembelajaran. Tesis, 27-70. http://eprints.walisongo.ac.id/355/4/UmiHanik_Tesis_Bab2.pdf

WHO. (2013). mental health action plan. Mental Health Action Plan 2013-2020, 86(1), 10-22. https://doi.org/10.1207/s15327752jpa8601_03

Yulianti, T. R. (2014). Peranan Orang Tua Dalam Mengembangkan Kreativitas Anak Usia Dini. Jurnal Empowerment, $\quad 4(1), \quad$ 11-24. journal.stkipsiliwangi.ac.id/index.php/empowerment/article/view/569/386

Zahrok, S., \& Suarmini, N. W. (2018). Peran Perempuan dalam Keluarga. IPTEK Journal of Proceedings Series, Vol. 3, No(5), 61. https://doi.org/10.12962/j23546026.y2018i5.4422 